\title{
AMINO ACID ANALOGS OF BENANOMICIN A THROUGH DESALANINEBENANOMICIN A
}

\author{
Daishiro Ikeda, Toshio Nishizuka, Shyh-Pyng Huang, \\ SHINICHI Kondo and TOMIO TAKEUCHI \\ Institute of Microbial Chemistry, \\ 3-14-23, Kamiosaki, Shinagawa-ku, Tokyo 141, Japan
}

(Received for publication May 12, 1992)

\begin{abstract}
Desalaninebenanomicin A has been synthesized in good yield by the cleavage of the amido bond of benanomicin A using MEERwEIN's reagent. This is a useful intermediate to prepare amino acid analogs of benanomicin A. MEERWEIN's reagent reacts with totally protected benanomicin $\mathrm{A}$ to give a stable imino ether. After deprotection, the imino ether is treated with aqueous acetone at reflux to afford a methyl ester of desalaninebenanomicin A. Desalaninebenanomicin A was coupled with a variety of amino acids by the active ester method to afford new benanomicin analogs.
\end{abstract}

Benanomicin A (1), isolated from the culture broth of Actinomadura sp. MH193-16F4, ${ }^{1)}$ exhibits excellent therapeutic effects against systemic fungal infections in mice and inhibits the infection of T-cell with human immunodeficiency virus and the syncytium formation by the virus. ${ }^{2,3)}$ Antibiotic 1 consists of a benzo[a]naphthacenedione, D-alanine and 3-O-(D-xylopyranosyl)-D-fucopyranose. ${ }^{4)}$ Pradimicin antibiotics produced by Actinomadura hibisca P157-2 are included in this group. ${ }^{5)}$

Among naturally occurring benanomicins, two amino acid analogs, $2^{\prime}$-demethylbenanomicin A (glycine analog) ${ }^{6)}$ and $2^{\prime}$-hydroxybenanomicin A (D-serine analog), ${ }^{7}$ show comparable antifungal activities to 1 . SAWADA and coworkers also isolated 2'-hydroxypradimicins (pradimicins FA-1 and FA-2) by the addition of D-serine to the culture medium. ${ }^{8)}$

In our studies on benanomicins, our attention was focused on the relationship between the structure of the amino acid moiety and the antifungal activity. Herein, we wish to report the chemical transformation of 1 into new amino acid analogs.

\section{Chemistry}

Our initial efforts were directed toward preparing desalaninebenanomicin A (6). On acid hydrolysis of 1 , the cleavage of glycosidic bonds preceded the amido cleavage. ${ }^{4)}$ Alkaline hydrolysis of 1 gave no desired product. The amido bond was extremely stable under the alkaline condition. Treatment of 1 with diazodiphenylmethane in a mixture of $N, N$-dimethylformamide and methanol, followed by the acetylation with acetic anhydride in pyridine afforded nona- $O$-acetyl-diphenylmethyl ester $\mathbf{2}$ in a good yield. An excess of MEERweIN's reagent (trimethyloxonium tetrafluoroborate is preferable to triethyloxonium tetrafluoroborate for this reaction) smoothly reacted with $\mathbf{2}$ in dry dichloromethane to yield a stable methyl imino ether-diphenylmethyl ester $\mathbf{3 a}$ along with methyl ester $\mathbf{3 b}$ and carboxylic acid $\mathbf{3 c} .{ }^{1} \mathrm{H}$ NMR spectrum of $\mathbf{3 a}$ showed the presence of a new methoxy group. Alkaline hydrolysis of a mixture of $3 \mathbf{a} \sim \mathbf{3} \mathbf{c}$ with $1 \mathrm{M}$ sodium hydroxide at room temperature, followed by the acidification gave an orange powder of benanomicin A methyl imino ether (4). On refluxing 4 in aqueous acetone for 3 hours, desalaninebenanomicin A methyl ester (5) was obtained in $44 \%$ yield from 1 . By the hydrolysis with hydrochloric acid, imino ether 4 reverted to amido 1. ${ }^{1} \mathrm{H}$ NMR spectrum of 5 revealed the presence of an aromatic methyl ester at $\delta 3.82$. The 
negative FAB-MS of 5 showed a parent peak at $m / z$ 770. The methyl ester 5 was hydrolyzed with $2 \mathrm{M}$ sodium hydroxide at $70^{\circ} \mathrm{C}$ gave 6 , which was an important key intermediate for the preparation of amino acid analogs of 1 . (Scheme 1)

Scheme 1. Synthesis of desalaninebenanomicin A.

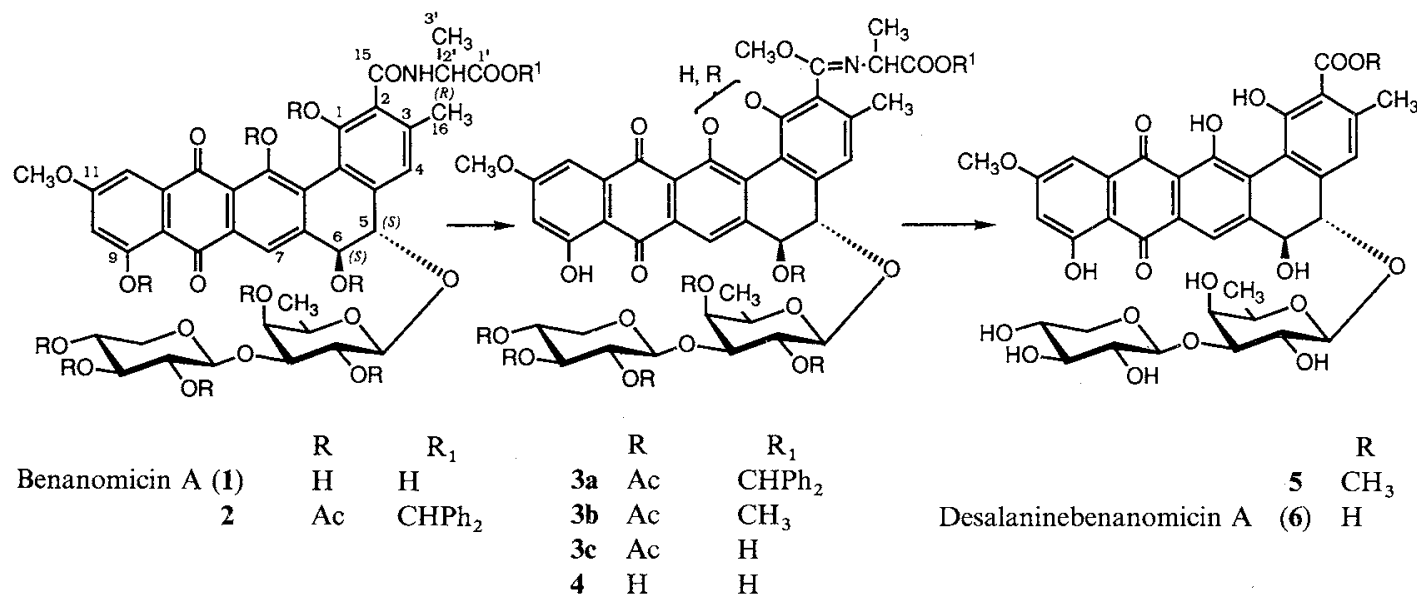

Fig. 1. Amino acid analogs of benanomicin A.

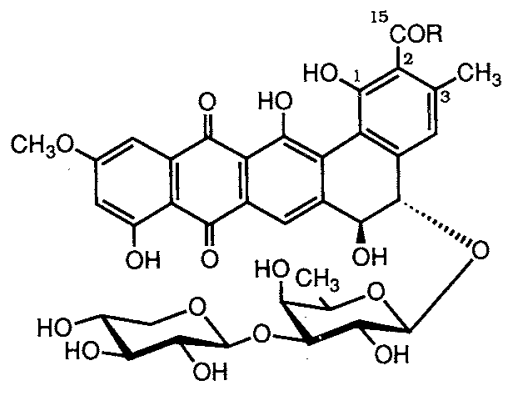

$\mathrm{R}$

8a L-Ala

8b D-Thr

$8 c \quad$ D-aThr

8d L-Thr

8e L-aThr

8 D-Asp

$8 \mathrm{NHCHCO}{ }_{2} \mathrm{H}$ (D-Butyrine)

8 D-Phe

8i D-Ser

$8 \mathrm{j} \quad \mathrm{NHCH}\left(\mathrm{CO}_{2} \mathrm{H}\right)_{2}$ (Aminomalonic acid)

8k $\mathrm{NHCH}_{2} \mathrm{CO}_{2} \mathrm{H}$ (Glycine)

$8 \mathrm{~N} \quad \mathrm{NHCH}_{2} \mathrm{CH}_{2} \mathrm{CO}_{2} \mathrm{H}$ ( $\beta$-Alanine)

$8 \mathrm{~m} \quad \mathrm{NHCH}_{2} \mathrm{CH}_{2} \mathrm{CH}_{2} \mathrm{CO}_{2} \mathrm{H} \quad(\gamma$-Aminobutyric acid)

8n $\mathrm{N}\left(\mathrm{CH}_{3}\right) \mathrm{CH}_{2} \mathrm{CO}_{2} \mathrm{H}$ (Sarcosine)

$80 \quad \mathrm{~N}\left(\mathrm{CH}_{2} \mathrm{CO}_{2} \mathrm{H}\right)_{2}$ (Iminodiacetic acid)

8p $\mathrm{NHCH}_{2} \mathrm{SO}_{3} \mathrm{H}$ (Aminomethanesulfonic acid)

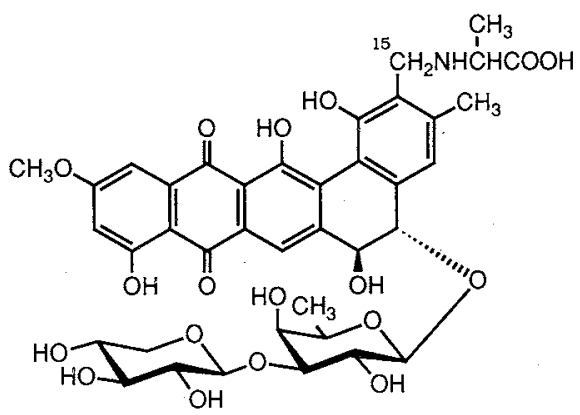

9 
After total $O$-acetylation of 6 , nonaacetate 7 was coupled with a variety of amino acids by the active ester method using i) $N$-hydroxybenzotriazole (HOBT) and $N, N^{\prime}$-dicyclohexylcarbodiimide (DCC), ii) p-hydroxyphenyldimethylsulfonium methylsulfate and DCC or iii) HOBT and 1-ethyl-3-(3-dimethylaminopropyl)carbodimide hydrochloride. The protected new benanomicin analogs were treated with $0.2 \mathrm{M}$ potassium carbonate and chromatographed on silica gel to give new benanomicin analogs $\mathbf{8}$. (Fig. 1)

The reduction of 4 with sodium borohydride in an aqueous ethanol gave 15-deoxobenanomicin $A$ (9). ${ }^{1} \mathrm{H}$ NMR of 9 hydrochloride in DMSO- $d_{6}$ revealed a singlet methylene signal at $\delta 4.22$. In ${ }^{13} \mathrm{C} \mathrm{NMR}$, a new methylene carbon instead of the amido carbon at C-15 position was observed at $\delta 43.3$.

\section{In Vitro Antifungal Activity}

Minimum inhibitory concentrations (MICs) of new benanomicin analogs, 8a, 8b, 8c, 8d, 8e, 8f, 8g, $\mathbf{8 j}$ and $\mathbf{8 1}$ against various fungi are summarized in Table 1 . The D-amino acid analogs retain the antifungal activity. The L-amino acid analogs, $8 \mathbf{a}, \mathbf{8 d}$ and $\mathbf{8 e}$, are essentially devoid of antifungal activity. D-Allothreonine (D-aThr) and D-butyrine analogs, $\mathbf{8 c}$ and $\mathbf{8 g}$ respectively, are slightly less active than $\mathbf{1}$. Interestingly, $\mathbf{8 c}$ is superior to $\mathrm{D}$-threonine analog, $\mathbf{8 b}$. However, D-phenylalanine analog, $\mathbf{8 h}$, markedly decreases the antifungal activity. Aminomalonic acid analog, $\mathbf{8 j}$, which has no asymmetric center in the amino acid moiety is weaker than 1 . When the distance between the amino group and carboxyl group in the amino acid moiety is increased, in the cases of $\beta$-alanine $\mathbf{8 1}$ and $\gamma$-aminobutyric acid $\mathbf{8 m}$, the antifungal activity falls. $N$-Substituted analogs, $\mathbf{8 n}$ and $\mathbf{8 0}$, and sulfonic acid analog, $\mathbf{8 p}$, in place of carboxylic acid, have no antifungal activity. The reduction of amido carbonyl at the $\mathrm{C}-15$ position leads to a completely

Table 1. Antifungal activity of benanomicin A (1) and amino acid analogs.

\begin{tabular}{|c|c|c|c|c|c|}
\hline \multirow{2}{*}{ Microorganism } & \multicolumn{5}{|c|}{$\mathrm{MIC}(\mu \mathrm{g} / \mathrm{ml})$} \\
\hline & 1 & $\mathbf{8 a}$ & $8 b$ & $8 c$ & $8 d$ \\
\hline Candida albicans 3147 & 6.25 & $>100$ & 25 & 12.5 & $>100$ \\
\hline C. tropicalis $\mathrm{F}-1$ & 6.25 & $>100$ & 25 & 12.5 & $>100$ \\
\hline C. pseudotropicalis $\mathrm{F}-2$ & 3.13 & 25 & 6.25 & 3.13 & 25 \\
\hline C. krusei F-5 & 3.13 & $>100$ & 12.5 & 6.25 & $>100$ \\
\hline Candida sp. YU-1200 & 6.25 & $>100$ & 12.5 & 12.5 & $>100$ \\
\hline Saccharomyces cerevisiae $\mathrm{F}-7$ & 3.13 & 25 & 12.5 & 6.25 & 50 \\
\hline Cryptococcus neoformans $\mathrm{F}-10$ & 1.56 & $>100$ & 12.5 & 3.13 & $>100$ \\
\hline Aspergillus niger F-16 & 12.5 & $>100$ & $>100$ & $>100$ & $>100$ \\
\hline Trichophyton asteroides 429 & 50 & $>100$ & $>100$ & $>100$ & $>100$ \\
\hline T. mentagrophytes F-15 (833) & 50 & $>100$ & $>100$ & $>100$ & $>100$ \\
\hline \multirow{2}{*}{ Microorganism } & \multicolumn{5}{|c|}{$\mathrm{MIC}(\mu \mathrm{g} / \mathrm{ml})$} \\
\hline & $8 \mathrm{e}$ & $8 f$ & $8 \mathrm{~g}$ & $8 j$ & 81 \\
\hline Candida albicans 3147 & $>100$ & 50 & 12.5 & 25 & $>100$ \\
\hline C. tropicalis $\mathrm{F}-1$ & $>100$ & 50 & 12.5 & 25 & $>50$ \\
\hline C. pseudotropicalis $\mathrm{F}-2$ & 25 & 12.5 & 3.13 & 6.25 & $>50$ \\
\hline C. krusei $\mathrm{F}-5$ & $>100$ & 50 & 12.5 & 25 & $>100$ \\
\hline Candida sp. YU-1200 & $>100$ & 50 & 12.5 & 25 & $>100$ \\
\hline Saccharomyces cerevisiae $\mathrm{F}-7$ & 25 & 12.5 & 3.13 & 6.25 & $>50$ \\
\hline Cryptococcus neoformans $F-10$ & $>100$ & 50 & 6.25 & 25 & $>50$ \\
\hline Aspergillus niger $\mathrm{F}-16$ & $>100$ & $>100$ & 100 & $>100$ & $>100$ \\
\hline Trichophyton asteroides 429 & $>100$ & $>100$ & $>100$ & $>100$ & $>50$ \\
\hline T. mentagrophytes $\mathrm{F}-15$ (833) & $>100$ & $>100$ & $>100$ & $>100$ & $>50$ \\
\hline
\end{tabular}


inactive alkyl amino analog 9. Methyl imino ether 4, which has a D-alanine residue similar to 9 , shows no antifungal activity.

We have synthesized a number of benanomicin analogs through an important intermediate 6 and evaluated their antifungal activities in vitro. The present study provides the first chemical transformation of the amino acid moiety of $\mathbf{1}$, which can be used in further derivatization. The antifungal activity of benanomicins entirely depends on the structure of the amino acid side chain. The structural requirements of the side chain at the $\mathrm{C}-15$ position for the antifungal activity are as follows: 1) An
Fig. 2. Presumed conformation of the amino acid moiety which is active against fungi.

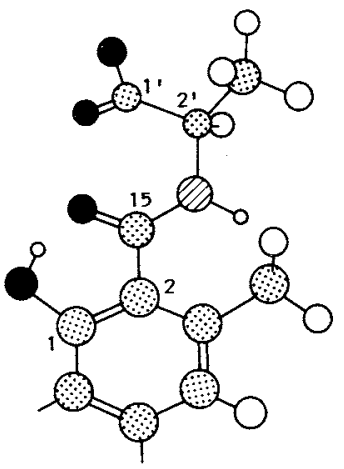

oxygen

Carbon

Hydrogen

Nitrogen

amido bond at C-15, 2) $\alpha$-amino acid, 3) $R$-configuration of the amino acid where the asymmetric carbon exists and 4) sterically unhindered substituent in the side chain. Antibiotic 1 binds to Candida albicans cells in the presence of calcium ion ${ }^{9)}$ and biologically inactive analogs show the negligible binding. ${ }^{7)}$ These structural features necessary for the amino acid might control the binding to fungal cell surface.

From results mentioned above, we presume that the steric and electrostatic interactions among the phenolic hydroxyl at $\mathrm{C}-1$ position, carbonyl in amido and terminal carboxyl group fix the conformation of the amino acid residue and the conformation plays an important role for the binding to fungi and the occurrence of the antifungal activity of $\mathbf{1}$. (Fig. 2)

\section{Experimental}

General

Mass spectra (FAB-MS) were measured on a Jeol JMX-SX102 mass spectrometer. ${ }^{1} \mathrm{H}$ and ${ }^{13} \mathrm{C} \mathrm{NMR}$ spectra were recorded on a Jeol JNM-GX400 spectrometer at $50^{\circ} \mathrm{C}$ unless otherwise noted.

Nona- $O$-acetylbenanomicin A Diphenylmethyl Ester (2)

To a solution of $1(3.0 \mathrm{~g})$ in a mixture of DMF $(50 \mathrm{ml})$ and $\mathrm{MeOH}(50 \mathrm{ml})$ was added diazodiphenylmethane $(1.1 \mathrm{~g})$. After stirring overnight, the solution was concentrated to half volume. To this was added water $(200 \mathrm{ml})$. The dark red precipitates were collected by filtration and washed with ethyl acetate $(200 \mathrm{ml})$ and water $(200 \mathrm{ml})$. Diphenylmethyl ester of $1(3.0 \mathrm{~g})$ was obtained in $83 \%$ yield. Negative FAB-MS $m / z 993\left(\mathrm{M}^{-}\right)$. This ester $(3.0 \mathrm{~g})$ was acetylated with acetic anhydride $(6 \mathrm{ml})$ in pyridine $(120 \mathrm{ml})$ at $50^{\circ} \mathrm{C}$ for 3 hours. After concentration, the obtained syrup was treated with water $(100 \mathrm{ml})$ to give yellow solid, which was washed with water. Compound $2(4.1 \mathrm{~g})$ was obtained as an yellow powder quantitatively. Negative FAB-MS $m / z \quad 1,370\left((\mathbf{M}-\mathbf{H})^{-}\right)$.

Hepta- $O$-acetylbenanomicin Methyl Imino Ethers $(3 \mathbf{a} \sim 3 \mathbf{c})$

To a solution of $2(4.2 \mathrm{~g})$ in anhydr dichloromethane $(80 \mathrm{ml})$ was added trimethyloxonium tetrafluoroborate (2.3 g). After stirring overnight at room temperature, a satd aq solution of $\mathrm{NaHCO}_{3}(100 \mathrm{ml})$ was added. After 30 minutes, the organic layer was washed by $5 \%$ aq citric acid solution and water, dried over anhydr $\mathrm{MgSO}_{4}$ and concentrated under reduced pressure to give a mixture of hepta- $O$-acetyl-imino ethers $(3 \mathbf{a} \sim 3 \mathbf{c})$. For the chemical and biological analysis, a part of the mixture was chromatographed on silica gel with hexane - ethyl acetate $(2: 3)$ to give diphenylmethyl ester $\mathbf{3 a}$, methyl ester $\mathbf{3 b}$ and carboxylic acid 3c in 3:1:5 ratio. 3a: Negative FAB-MS $m / z 1,300\left((\mathrm{M}-\mathrm{H})^{-}\right) .{ }^{1} \mathrm{H}$ NMR $\left(\mathrm{CDCl}_{3}\right.$, ambient temperature) $\delta 3.87$ and $3.91\left(\mathrm{OCH}_{3}\right), 3.94$ and $3.95\left(\mathrm{OCH}_{3}\right), 6.73\left(\mathrm{CH}\left(\mathrm{C}_{6} \mathrm{H}_{5}\right)_{2}\right)$ and $7.30 \sim 7.33\left(\mathrm{CH}\left(\mathrm{C}_{6} H_{5}\right)_{2}\right)$. 
3b: Negative FAB-MS $m / z 1,148\left((\mathrm{M}-\mathrm{H})^{-}\right) .{ }^{1} \mathrm{H}$ NMR $\left(\mathrm{CDCl}_{3}\right.$, ambient temperature $\delta 3.70\left(\mathrm{CO}_{2} \mathrm{CH}_{3}\right)$, 3.85 and $3.93\left(\mathrm{OCH}_{3}\right)$ and $3.95\left(\mathrm{OCH}_{3}\right)$. 3c: Negative FAB-MS $m / z 1,134\left((\mathrm{M}-\mathrm{H})^{-}\right) .{ }^{1} \mathrm{H}$ NMR $\left(\mathrm{CDCl}_{3}\right.$, ambient temperature) $\delta 3.79\left(\mathrm{OCH}_{3}\right)$ and $3.98\left(\mathrm{OCH}_{3}\right)$. These NMR spectra showed that 3a $\sim 3 \mathbf{c}$ contained rotamers.

\section{Benanomicin A Methyl Imino Ether (4)}

The mixture of acetyl-imino ethers $(3 \mathbf{3 a} \sim 3 \mathbf{b})(3.9 \mathrm{~g})$ was treated with $1 \mathrm{M} \mathrm{NaOH}(40 \mathrm{ml})$ in $\mathrm{MeOH}$ $(40 \mathrm{ml})$ at room temperature overnight. After evaporation of $\mathrm{MeOH}, 1 \mathrm{M} \mathrm{HCl}$ was added to the solution to $\mathrm{pH}$ 1.6. An orange solid was precipitated, which was collected by centrifugation and washed with water and dried. Imino ether $4(2.1 \mathrm{~g})$ was obtained. This compound was used in the next reaction without further purification. Compound $\mathbf{4}$ was purified on silica gel column for preparing an analytical sample. Negative FAB-MS $m / z 841\left(\mathrm{M}^{-}\right)$.

Desalaninebenanomicin A Methyl Ester (5)

A solution of $4(2.0 \mathrm{~g})$ in a mixture of acetone $(60 \mathrm{ml})$ and water $(30 \mathrm{ml})$ was refluxed for 3 hours. After evaporation of acetone, a red solid was precipitated. The solid was collected by centrifugation, dried and chromatographed on silica gel with chloroform-butanol-pyridine-water $(40: 20: 25: 3)$ to give desalanine-methyl ester $5(1.36 \mathrm{~g})$. Negative FAB-MS $m / z 770\left(\mathrm{M}^{-}\right) .{ }^{1} \mathrm{H}$ NMR (DMSO- $\left.d_{6}\right) \delta 3.82$ $\left(\mathrm{CO}_{2} \mathrm{CH}_{3}\right)$ and $3.94\left(11-\mathrm{OCH}_{3}\right) \cdot{ }^{13} \mathrm{C} \mathrm{NMR} \delta 168.8\left(\mathrm{CO}_{2} \mathrm{CH}_{3}\right)$ and $52.0\left(\mathrm{CO}_{2} \mathrm{CH}_{3}\right)$.

Desalaninebenanomicin A (6)

Desalanine-methyl ester $5(640 \mathrm{mg})$ was treated with $1.6 \mathrm{M} \mathrm{NaOH}$ in aq $\mathrm{MeOH}(64 \mathrm{ml})$ at $70^{\circ} \mathrm{C}$ for 24 hours. After acidification with $3 \mathrm{M} \mathrm{HCl}$ to $\mathrm{pH} 1.6$ in an ice bath, the precipitates were collected by filtration. The obtained solid was chromatographed on silica gel with chloroform - butanol - pyridine - water $(4: 3: 5: 1)$ to give 6 as a pyridinium salt. The product was dissolved in water $(50 \mathrm{ml})$, acidified with $1 \mathrm{M}$ $\mathrm{HCl}$ to $\mathrm{pH} 1.6$. The precipitates were collected by centrifugation to give $6(430 \mathrm{mg})$. Negative FAB-MS $m / z 756\left(\mathrm{M}^{-}\right) .{ }^{1} \mathrm{H}$ NMR (DMSO- $\left.d_{6}\right) \delta 1.13\left(\mathrm{~d}, J=6.4 \mathrm{~Hz}, 6^{\prime \prime}-\mathrm{H}\right), 2.47(16-\mathrm{H}), 3.95\left(11-\mathrm{OCH}_{3}\right), 4.42(\mathrm{~d}$, $\left.J=7 \mathrm{~Hz}, 1^{\prime \prime \prime}-\mathrm{H}\right), 4.53(\mathrm{~d}, J=9 \mathrm{~Hz}, 5-\mathrm{H}), 4.62\left(\mathrm{~d}, J=9 \mathrm{~Hz}, 1^{\prime \prime}-\mathrm{H}\right), 4.62(\mathrm{~d}, J=9 \mathrm{~Hz}, 6-\mathrm{H}), 6.90(\mathrm{~d}, J=2 \mathrm{~Hz}$, $10-\mathrm{H}), 7.20(4-\mathrm{H}), 7.28(\mathrm{~d}, J=2 \mathrm{~Hz}, 12-\mathrm{H}), 8.05(7-\mathrm{H})$ and $12.81(9-\mathrm{OH}) .{ }^{13} \mathrm{C}$ NMR $\delta 187.0(\mathrm{C}-13)$, 185.1 (C-8), 171.1 (C-15), 165.9 (C-11), 164.6 (C-9), 157.6 (C-14), 155.5 (C-1), 147.4 (C-6a), 140.6 (C-4a), 139.4 (C-3), 134.5 (C-12a), 131.4 (C-7a), 125.3 (C-2 and C-14a), 118.2 (C-4), 115.4 (C-13a), 114.8 (C-7),

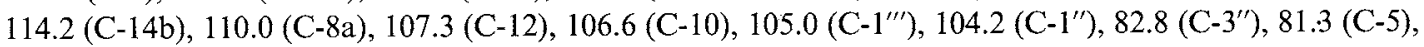
$75.9\left(\mathrm{C}-3^{\prime \prime \prime}\right), 73.5\left(\mathrm{C}-2^{\prime \prime \prime}\right), 71.6(\mathrm{C}-6), 70.3\left(\mathrm{C}-4^{\prime \prime}\right), 70.0\left(\mathrm{C}-5^{\prime \prime}\right), 69.9\left(\mathrm{C}-2^{\prime \prime}\right), 69.3\left(\mathrm{C}-4^{\prime \prime \prime}\right) 65.5\left(\mathrm{C}-5^{\prime \prime \prime}\right), 56.2$ $\left(11-\mathrm{OCH}_{3}\right), 21.5(\mathrm{C}-16)$ and $16.2\left(\mathrm{C}-6^{\prime \prime}\right)$.

Nona- $O$-acetyldesalaninebenanomicin A (7)

Compound $6(640 \mathrm{mg})$ was acetylated with acetic anhydride $(5 \mathrm{ml})$ in pyridine $(10 \mathrm{ml})$. After 3 hours at $70^{\circ} \mathrm{C}$, the solution was concentrated to solid which was chromatographed on silica gel with chloroform - MeOH - water (1000:20:1) to give nonaacetate $7(643 \mathrm{mg})$. Negative FAB-MS m/z 1,134 (M- $\left.{ }^{-}\right)$.

$\left(2^{\prime} S, 3^{\prime} R\right)-3^{\prime}-$ Hydroxy-3'-methylbenanomicin A (8d) (L-Thr Analog)

To a solution of $7(100 \mathrm{mg})$ and HOBT $(74 \mathrm{mg})$ in acetonitrile $(4 \mathrm{ml})$ were added a solution of L-threonine diphenylmethyl ester $p$-toluenesulfonate $(168 \mathrm{mg})$ and $N$-methylmorpholine $(60 \mu \mathrm{l})$ in acetonitrile $(3 \mathrm{ml})$ and $\mathrm{DCC}(57 \mathrm{mg})$ at $4^{\circ} \mathrm{C}$. After 4 hours at room temperature, acetic acid $(0.2 \mathrm{ml})$ was added. Precipitates were filtered and the filtrate was concentrated to solid. The solid was dissolved in ethyl acetate $(20 \mathrm{ml})$ and the solution was washed with $10 \%$ citric acid solution, satd $\mathrm{NaHCO}_{3}$ solution and water, dried over anhydr $\mathrm{MgSO}_{4}$ and evaporated to give the product $(130 \mathrm{mg})$. The product was treated with $0.2 \mathrm{M} \mathrm{aq} \mathrm{K}_{2} \mathrm{CO}_{3}$ in a mixture of $\mathrm{MeOH}(5 \mathrm{ml})$ and pyridine $(3 \mathrm{ml})$ at $70^{\circ} \mathrm{C}$ overnight. After acidifying with $1 \mathrm{M} \mathrm{HCl}$ to $\mathrm{pH} 2.0$, precipitates were collected by centrifugation and chromatographed on silica gel with chloroform - butanol-pyridine - water $(40: 20: 25: 3)$. The obtained pyridinium salt was dissolved in water and the $\mathrm{pH}$ of the solution was adjusted to $\mathrm{pH} 2.0$ with $2 \mathrm{M} \mathrm{HCl}$. Precipitates were collected by 
centrifugation, washed with water and dried to give $8 \mathrm{~d}(12 \mathrm{mg})$. Negative FAB-MS $m / z 857\left(\mathrm{M}^{-}\right) .{ }^{1} \mathrm{H}$ NMR (DMSO- $\left.d_{6}\right) \delta 1.22\left(3^{\prime}-\mathrm{CH}_{3}\right), 4.19\left(3^{\prime}-\mathrm{H}\right), 4.44\left(2^{\prime}-\mathrm{H}\right)$ and $7.76(\mathrm{NH}) .{ }^{13} \mathrm{C}$ NMR $\delta 171.7\left(\mathrm{C}-1^{\prime}\right)$, $167.3(\mathrm{C}-15), 66.4\left(\mathrm{C}-3^{\prime}\right), 58.0\left(\mathrm{C}-2^{\prime}\right)$ and $20.2\left(3^{\prime}-\mathrm{CH}_{3}\right)$.

Benanomicin A and Amino Acid Analogs of Benanomicin A $(\mathbf{1}, \mathbf{8 a} \sim 8 \mathrm{c}, 8 \mathbf{8} \sim \mathbf{8 h}, \mathbf{8 j} \sim \mathbf{8 1}, \mathbf{8 n}$ and $8 \mathbf{n o})$ These compounds were prepared by a similar procedure used for $\mathbf{8 d}$.

Benanomicin A (1) (40 mg) was prepared from 7 (100 mg) and D-alanine benzyl ester $p$-toluenesulfonate $(128 \mathrm{mg})$. The properties of synthetic 1 were identical with the natural antibiotic in all respects. ${ }^{1,4)}$

$2^{\prime}$-Epi-benanomicin A (8a, L-Ala analog) $(41 \mathrm{mg})$ was prepared from $7(100 \mathrm{mg})$ and $\mathrm{L}$-alanine benzyl ester $p$-toluenesulfonate $(129 \mathrm{mg})$. Negative FAB-MS $m / z 827\left(\mathrm{M}^{-}\right) .{ }^{1} \mathrm{H}$ NMR (DMSO- $\left.d_{6}\right) \delta 1.38\left(3^{\prime}-\mathrm{H}\right)$, $4.46\left(2^{\prime}-\mathrm{H}\right)$ and $8.42(\mathrm{NH}) .{ }^{13} \mathrm{C}$ NMR $\delta 173.8\left(\mathrm{C}-1^{\prime}\right), 166.9(\mathrm{C}-15), 47.6\left(\mathrm{C}-2^{\prime}\right)$ and $16.8\left(\mathrm{C}-3^{\prime}\right)$.

$\left(2^{\prime} R, 3^{\prime} S\right)$-3'-Hydroxy-3'-methylbenanomicin A $(\mathbf{8 b}, \mathrm{D}-\mathrm{Thr}$ analog) $(30 \mathrm{mg})$ was prepared from 7 $(100 \mathrm{mg})$ and $\mathrm{D}$-threonine diphenylmethyl ester $p$-toluenesulfonate $(168 \mathrm{mg})$. Negative FAB-MS $\mathrm{m} / \mathrm{z} 857$ $\left(\mathrm{M}^{-}\right)$. ${ }^{1} \mathrm{H}$ NMR (DMSO- $\left.d_{6}\right) \delta 1.20\left(3^{\prime}-\mathrm{CH}_{3}\right), 4.18\left(3^{\prime}-\mathrm{H}\right), 4.42\left(2^{\prime}-\mathrm{H}\right)$ and $7.74(\mathrm{NH}) .{ }^{13} \mathrm{C}$ NMR $\delta 171.7$ $\left(\mathrm{C}-1^{\prime}\right), 167.2(\mathrm{C}-15), 66.4\left(\mathrm{C}-3^{\prime}\right), 57.9\left(\mathrm{C}-2^{\prime}\right)$ and $20.2\left(3^{\prime}-\mathrm{CH}_{3}\right)$.

$\left(2^{\prime} R, 3^{\prime} R\right)-3^{\prime}-$ Hydroxy-3'-methylbenanomicin A (8c, D-aThr analog) $(11 \mathrm{mg})$ was prepared from 7 $(100 \mathrm{mg})$ and D-allothreonine diphenylmethyl ester $p$-toluenesulfonate $(168 \mathrm{mg})$. Negative FAB-MS $m / z$ $857\left(\mathrm{M}^{-}\right) .{ }^{1} \mathrm{H}$ NMR (DMSO- $\left.d_{6}\right) \delta 1.20\left(3^{\prime}-\mathrm{CH}_{3}\right), 3.96\left(3^{\prime}-\mathrm{H}\right), 4.42\left(2^{\prime}-\mathrm{H}\right)$ and $8.18(\mathrm{NH}) .{ }^{13} \mathrm{C}$ NMR $\delta 171.6\left(\mathrm{C}-1^{\prime}\right), 167.2(\mathrm{C}-15), 66.6\left(\mathrm{C}-3^{\prime}\right), 58.5\left(\mathrm{C}-2^{\prime}\right)$ and $19.9\left(3^{\prime}-\mathrm{CH}_{3}\right)$.

$\left(2^{\prime} S, 3^{\prime} S\right)-3^{\prime}$-Hydroxy-3'-methylbenanomicin A (8e, L-aThr analog) $(6.4 \mathrm{mg})$ was prepared from 7 $(100 \mathrm{mg})$ and L-allothreonine diphenylmethyl ester $p$-toluenesulfonate $(168 \mathrm{mg})$. Negative FAB-MS $\mathrm{m} / \mathrm{z}$ $857\left(\mathrm{M}^{-}\right) .{ }^{1} \mathrm{H}$ NMR (DMSO-d $\left.d_{6}\right) \delta 1.22\left(3^{\prime}-\mathrm{CH}_{3}\right), 4.00\left(3^{\prime}-\mathrm{H}\right), 4.41\left(2^{\prime}-\mathrm{H}\right)$ and $8.15(\mathrm{NH}) .{ }^{13} \mathrm{C}$ NMR $\delta 171.5\left(\mathrm{C}-1^{\prime}\right), 167.0(\mathrm{C}-15), 66.6\left(\mathrm{C}-3^{\prime}\right), 58.5\left(\mathrm{C}-2^{\prime}\right)$ and $19.2\left(3^{\prime}-\mathrm{CH}_{3}\right)$.

3'-Carboxybenanomicin A (8f, D-Asp analog) (38 mg) was prepared from $7(80 \mathrm{mg})$ and D-aspartic acid dibenzyl ester $p$-toluenesulfonate $\left(142 \mathrm{mg}\right.$ ). Negative FAB-MS $m / z$ 871 $\left(\mathrm{M}^{-}\right) .{ }^{1} \mathrm{H}$ NMR (DMSO- $d_{6}$ ) $\delta 2.67$ and $2.81\left(3^{\prime}-\mathrm{Ha}\right.$ and $\left.3^{\prime}-\mathrm{Hb}\right), 4.78\left(2^{\prime}-\mathrm{H}\right)$ and $8.39(\mathrm{NH}) .{ }^{13} \mathrm{C}$ NMR $\delta 172.0$ and $171.4\left(\mathrm{C}-1^{\prime}\right.$ and $\left.3^{\prime}-\mathrm{CO}_{2} \mathrm{H}\right), 166.8(\mathrm{C}-15), 48.7\left(\mathrm{C}-2^{\prime}\right)$ and $35.8\left(\mathrm{C}-3^{\prime}\right)$.

$\left(2^{\prime} R\right)-3^{\prime}$-Methylbenanomicin A (8g, D-butyrine analog) $(15 \mathrm{mg})$ was prepared from $7(100 \mathrm{mg})$ and D-butyrine diphenylmethyl ester $p$-toluenesulfonate $(168 \mathrm{mg})$. Negative FAB-MS $m / z 841\left(\mathrm{M}^{-}\right) .{ }^{1} \mathrm{H}$ NMR $\left(\right.$ DMSO- $\left.d_{6}\right) \delta 0.97\left(3^{\prime}-\mathrm{CH}_{3}\right), 1.76\left(3^{\prime}-\mathrm{Ha}\right.$ and $\left.3^{\prime}-\mathrm{Hb}\right), 4.34\left(2^{\prime}-\mathrm{H}\right)$ and $8.30(\mathrm{NH}){ }^{13} \mathrm{C}$ NMR $\delta 173.2\left(\mathrm{C}-1^{\prime}\right)$, $167.1(\mathrm{C}-15), 53.4\left(\mathrm{C}-2^{\prime}\right), 24.0\left(\mathrm{C}-3^{\prime}\right)$ and $10.3\left(3^{\prime}-\mathrm{CH}_{3}\right)$.

3'-Phenylbenanomicin A (8h, D-Phe analog) $(19 \mathrm{mg})$ was prepared from $7(80 \mathrm{mg})$ and D-phenylalanine benzyl ester $p$-toluenesulfonate $(125 \mathrm{mg})$. Negative FAB-MS $m / z 903\left(\mathrm{M}^{-}\right) .{ }^{1} \mathrm{H}$ NMR (DMSO- $\left.d_{6}\right) \delta 3.2$ and $3.8\left(3^{\prime}-\mathrm{Ha}\right.$ and $\left.3^{\prime}-\mathrm{Hb}\right), 4.8\left(2^{\prime}-\mathrm{H}\right), 7.25 \sim 7.45\left(\mathrm{C}_{6} \mathrm{H}_{5}\right)$ and $8.57(\mathrm{NH}) .{ }^{13} \mathrm{C}$ NMR $\delta 172.7\left(\mathrm{C}-1^{\prime}\right), 167.1$ $(\mathrm{C}-15), 53.6\left(\mathrm{C}-2^{\prime}\right)$ and $36.3\left(\mathrm{C}-3^{\prime}\right)$.

2'-Carboxy-2'-demethylbenanomicin A (8j, aminomalonic acid analog) disodium salt ( $38 \mathrm{mg})$ was prepared from $7(100 \mathrm{mg})$ and aminomalonic acid diethyl ester hydrochloride $(77 \mathrm{mg})$. Negative FAB-MS $m / z 901\left((\mathrm{M}+2 \mathrm{Na}-2 \mathrm{H})^{-}\right.$, disodium salt $) .{ }^{1} \mathrm{H}$ NMR $\left(\mathrm{D}_{2} \mathrm{O}, 70^{\circ} \mathrm{C}\right) \delta 3.81\left(2^{\prime}-\mathrm{H}\right) .{ }^{13} \mathrm{C}$ NMR $\delta 175.4$ and $172.0\left(\right.$ each $\left.\mathrm{CO}_{2} \mathrm{H}\right)$ and $72.4\left(\mathrm{C}-2^{\prime}\right)$.

2'-Demethylbenanomicin A (8k, Gly analog) $(46 \mathrm{mg})$ was prepared from 7 (100 $\mathrm{mg})$ and glycine ethyl ester hydrochloride $(66 \mathrm{mg})$. The properties of $\mathbf{8 k}$ were identical with natural product in all respects. $\left.{ }^{6}\right)$

$N$-(2-Carboxyethyl)desalaninebenanomicin A-amide (81, $\beta$-Ala analog) $(41 \mathrm{mg})$ was prepared from 7 $(80 \mathrm{mg})$ and $\beta$-alanine methyl ester trifluoroacetate $(57 \mathrm{mg})$. Negative FAB-MS $m / z 827\left(\mathrm{M}^{-}\right) .{ }^{1} \mathrm{H}$ NMR $\left(\mathrm{DMSO}-d_{6}\right) \delta 2.52\left(3^{\prime}-\mathrm{H}\right), 3.46\left(3^{\prime}-\mathrm{H}\right)$ and $8.11(\mathrm{NH}) .{ }^{13} \mathrm{C}$ NMR $\delta 172.5\left(\mathrm{C}-1^{\prime}\right), 167.1(\mathrm{C}-15), 35.0\left(\mathrm{C}-3^{\prime}\right)$ and $33.6\left(\mathrm{C}-2^{\prime}\right)$.

2 -Demethyl- $N$-methylbenanomicin A (8n, Sar analog) (19 mg) was prepared from $7(80 \mathrm{mg})$ and sarcosine ethyl ester hydrochloride $(45 \mathrm{mg})$. Negative FAB-MS $m / z 827\left(\mathrm{M}^{-}\right) .{ }^{1} \mathrm{H}$ NMR (DMSO- $d_{6}$ ) $\delta 2.80$ and $2.92\left(\mathrm{~N}-\mathrm{CH}_{3}\right.$, rotamer $)$ and 3.81 and $3.87\left(2^{\prime}-\mathrm{H}\right.$, rotamer $) .{ }^{13} \mathrm{C}$ NMR $\delta 170.2\left(\mathrm{C}-1^{\prime}\right), 168.3$ (C-15), 47.9 and $47.7\left(\mathrm{C}-2^{\prime}\right.$, rotamer) and 36.0 and $35.9\left(\mathrm{~N}-\mathrm{CH}_{3}\right.$, rotamer).

$N$-Carboxymethyl-2'-demethylbenanomicin A (8o, iminodiacetic acid analog) $(7 \mathrm{mg})$ was prepared from $7(100 \mathrm{mg})$ and iminodiacetic acid bis(diphenylmethyl)ester $p$-toluenesulfonate $(240 \mathrm{mg})$. Negative FAB-MS $m / z 871\left(\mathrm{M}^{-}\right)$. ${ }^{1} \mathrm{H}$ NMR (disodium salt, $\left.\mathrm{D}_{2} \mathrm{O}, 70^{\circ} \mathrm{C}\right) \delta 3.95$ and $3.98\left(3^{\prime}-\mathrm{H}\right.$, rotamer) and 4.22 and $4.23\left(2^{\prime}-\mathrm{H}\right.$, rotamer). ${ }^{13} \mathrm{C}$ NMR $\delta 181.2,177.2$ and $176.9\left(\mathrm{C}-1^{\prime}, \mathrm{C}-4^{\prime}\right.$ and $\left.\mathrm{C}-15\right), 54.2\left(\mathrm{C}-2^{\prime}\right)$ and $50.9\left(\mathrm{C}-3^{\prime}\right)$. 


\section{2'-Hydroxybenanomicin A (8i, D-Ser Analog)}

To a solution of $7(104 \mathrm{mg})$ in acetonitrile $(3 \mathrm{ml})$ were added $p$-hydroxyphenyldimethylsulfonium methylsulfate $(25 \mathrm{mg})$ and $\mathrm{DCC}(19 \mathrm{mg})$ at $4^{\circ} \mathrm{C}$. After stirring at room temperature overnight, precipitates were removed. The filtrate was concentrated to give a water soluble active ester. To a solution of the active ester in a mixture of acetonitrile $(0.5 \mathrm{ml})$ and $\mathrm{H}_{2} \mathrm{O}(1 \mathrm{ml})$ was added a solution of D-serine $N, N$-dicyclohexylamine salt $(200 \mathrm{mg})$ in a mixture of acetonitrile $(0.27 \mathrm{ml})$ and water $(0.45 \mathrm{ml})$. After stirring for 3 days at room temperature, $1 \mathrm{M} \mathrm{aq} \mathrm{K}_{2} \mathrm{CO}_{3}(4 \mathrm{ml})$ and $\mathrm{MeOH}(4 \mathrm{ml})$ were added to the reaction solution. Acidification of the solution with $1 \mathrm{M} \mathrm{HCl}$ to $\mathrm{pH} 1.6$, followed by centrifugation afforded a red solid. The solid was chromatographed on silica gel. with chloroform - butanol - pyridine - water $(4: 3: 5: 1)$ to give a product. The product was reprecipitated by the similar procedure to $8 \mathbf{d}$ to give D-serine analog $8 \mathbf{i}(15 \mathrm{mg})$. The properties of $8 \mathbf{i}$ were identical with the natural antibiotic in all respects. ${ }^{73}$

\section{$N$-(3-Carboxypropy1)desalaninebenanomicin A-amide (8m, GABA Analog)}

$\gamma$-Aminobutyric acid analog $8 \mathrm{~m}(7 \mathrm{mg})$ was prepared from $7(65 \mathrm{mg})$ and $\gamma$-aminobutyric acid tetra-butylammonium salt $(70 \mathrm{mg})$ by the similar procedure to $8 \mathbf{i}$. Negative FAB-MS $m / z 841\left(\mathrm{M}^{-}\right) .{ }^{1} \mathrm{H}$ NMR (DMSO- $\left.d_{6}\right) \delta 1.76\left(3^{\prime}-\mathrm{H}\right), 2.32\left(2^{\prime}-\mathrm{H}\right), 3.25\left(4^{\prime}-\mathrm{H}\right)$ and $8.10(\mathrm{NH}),{ }^{13} \mathrm{C}$ NMR $\delta 173.9\left(\mathrm{C}-1^{\prime}\right), 167.0$ (C-15), $38.1\left(\mathrm{C}-4^{\prime}\right), 31.0\left(\mathrm{C}-2^{\prime}\right)$ and $24.4\left(\mathrm{C}-3^{\prime}\right)$.

\section{$N$-(Sulfomethyl)desalaninebenanomicin A-amide (8p, Aminomethanesulfonic Acid Analog)}

Compound 8p (10 mg) was prepared from $7(100 \mathrm{mg})$ and aminomethanesulfonic acid tetrabutylammonium salt (129 mg) with HOBT $(74 \mathrm{mg})$ and water soluble 1-ethyl-3-(3-dimethylaminopropyl)carbodiimide hydrochloride $(53 \mathrm{mg})$ in DMF by the similar work up to $8 \mathbf{i}$. Negative FAB-MS $\mathrm{m} / \mathrm{z} 849$ $\left(\mathrm{M}^{-}\right) .{ }^{1} \mathrm{H}$ NMR (sodium salt, $\left.\mathrm{D}_{2} \mathrm{O}, 70^{\circ} \mathrm{C}\right) \delta 4.63\left(1^{\prime}-\mathrm{H}\right) .{ }^{13} \mathrm{C}$ NMR $\delta 173.2(\mathrm{C}-15)$ and $57.1\left(\mathrm{C}-1^{\prime}\right)$.

\section{5-Deoxobenanomicin A (9)}

To a solution of 4 sodium salt $(73 \mathrm{mg})$ in aq EtOH $(6 \mathrm{ml})$ was added a solution of $\mathrm{NaBH}_{4}(21 \mathrm{mg})$ in $\mathrm{EtOH}(0.5 \mathrm{ml})$ at $-30^{\circ} \mathrm{C}$. After stirring for 4 hours at this temperature, the solution was concentrated to solid. The residue was chromatographed on silica gel with chloroform - butanol - pyridine - water $(4: 4: 7: 2)$ to give a product. The product was dissolved in water $(10 \mathrm{ml})$. The solution was acidified with $2 \mathrm{M} \mathrm{HCl}$ to $\mathrm{pH} 2.0$. Precipitates were collected by centrifugation to give 9 hydrochloride $(8 \mathrm{mg})$. Negative FAB-MS $m / z 813\left(\mathrm{M}^{-}\right) .{ }^{1} \mathrm{H}$ NMR (DMSO- $\left.d_{6}\right) \delta 1.53\left(3^{\prime}-\mathrm{H}\right), 4.00\left(2^{\prime}-\mathrm{H}\right)$ and $4.22(15-\mathrm{H}) .{ }^{13} \mathrm{C}$ NMR $\delta 170.8\left(\mathrm{C}-1^{\prime}\right)$, $55.9\left(\mathrm{C}-2^{\prime}\right), 43.3(\mathrm{C}-15)$ and $16.2\left(\mathrm{C}-3^{\prime}\right)$.

\section{Antifungal Activity}

MICs on a glucose - nutrient agar were determined by the 2-fold agar dilution method after incubation at $27^{\circ} \mathrm{C}$ for 42 hours according to the method described in a preceding paper. ${ }^{3)}$

\section{References}

1) Takeuchi, T.; T. Hara, H. Naganawa, M. Okada, M. Hamada, H. Umezawa, S. Gomi, M. Sezaki \& S. Kondo: New antifungal antibiotics, benanomicins $\mathrm{A}$ and $\mathrm{B}$ from an Actinomycete. J. Antibiotics 41: 807 811, 1988

2) Hoshino, H.; J. SEKI \& T. TAKeUCHI: New antifungal antibiotics, benanomicins A and B inhibit infection of T-cell with human immunodeficiency virus (HIV) and syncytium formation by HIV. J. Antibiotics 42: 344 346, 1989

3) Kondo, S.; S. Goma, D. Ikeda, M. Hamada, T. Takeuchi, H. Iwai, J. Seki \& H. Hoshino: Antifungal and antiviral activities of benanomicins and their analogues. J. Antibiotics 44: 1228 1236, 1991

4) Gomi, S.; M. Sezaki, S. Kondo, T: Hara, H. Naganawa \& T. Takeuchi: "The structures of new antifungal antibiotics, benanomicins A and B. J. Antibiotics 41: 1019 1028, 1988

5) Tsunakawa, M.; M. Nishio, H. Ohkuma, T. Tsuno, M. Konishi, T. Naito, T, Oki \& H. Kawaguchi: The structures of pradimicins A, B, and C: A novel family of antifungal antibiotics. J. Org. Chem. 54: 2532 2536, 1989

6) Kondo, S.; S. GOMi, K. Uotani, S. INOUYE \& T. TAKEuChI: Isolation of new minor benanomicins. J. Antibiotics 44: $123 \sim 129,1991$

7) Kondo, S; S. Gomi, K. Uotani, S. Miyakawa, S. Inouye, D. Ikeda \& T. Takeuchi: New hydroxybenanomicins produced by Actinomadura. Drugs Exp. Clin. Res., 18 (6): 1992, in press

8) Sawada, Y.; M. Hatori, H. Yamamoto, M. Nisho, T. Miyaki \& T. OkI: New antifungal antibiotics pradimicins 
FA-1 and FA-2: D-Serine analogs of pradimicins A and C. J. Antibiotics 43: 1223 1229, 1990

9) Yamaguchi, H.; S. Inouye, Y. Orikasa, H. Tohyama, K. Komuro, S. Gomi, S. Ohuchi, T. Matsumoto, M. Yamaguchi, T. Hiratani, K. Uchida, Y. Ohsumi, S. Kondo \& T. Takeuchi: A novel antifungal antibiotic, benanomicin A. In Recent Progress in Antifungal Chemotherapy. Ed., H. YAMAGUChl et al., pp. 393 401, Marcel Dekker, 1991 